\title{
Wind-blown flux rates derived from drifts at arctic snow fences
}

\author{
Matthew STURM, ${ }^{1}$ Svetlana STUEFER ${ }^{2}$ \\ ${ }^{1}$ US Army Cold Regions Research and Engineering Laboratory, Fort Wainwright, AK, USA \\ E-mail: matthew.sturm@usace.army.mil \\ ${ }^{2}$ Department of Civil and Environmental Engineering, Water and Environmental Research Center, \\ University of Alaska Fairbanks, Fairbanks, AK, USA
}

\begin{abstract}
Historically, there has been considerable interest in establishing the relationship between wind-blown snow flux $(Q)$ and wind speed. By monitoring the drift growth at snow fences in Arctic Alaska during three winters, we computed $Q$ for 36 distinct transport events. Each fence was instrumented with depth sounders to measure deposition rates. The majority of events (31) occurred between November and February, despite winter extending from October to June. On average, five substantial snow deposition events (SDEs) occurred at each fence per winter. The mean flux during SDEs was 0.16, 0.19 and $0.29 \mathrm{~kg} \mathrm{~s}^{-1} \mathrm{~m}^{-1}$ at Barrow, Imnavait Creek and Franklin Bluffs, respectively, the differences in $Q$ explained by the different wind regimes at the three sites. To place these flux measurements in perspective, we reviewed all previous experimental values of $Q$, with special attention to height and time over which the fluxes were measured. The new data help fill a range of wind speeds $\left(12-18 \mathrm{~m} \mathrm{~s}^{-1}\right)$ where prior results have been sparse. Combined, the full data define a diffuse cloud best represented by upper and lower bounding equations $Q_{U}=1.3 \times 10^{-3} w^{2.5}$ and $Q_{L}=3.3 \times 10^{-9} w^{6.5}$, where $w$ is wind speed $\left(>5 \mathrm{~m} \mathrm{~s}^{-1}\right)$. We suggest that these bounds, rather than a single equation, provide the best way to estimate snow fluxes.
\end{abstract}

\section{INTRODUCTION}

Blowing snow is common wherever there is wind and snow. It is common on the Greenland ice cap and the Antarctic ice sheet (Mahesh and others, 2003), on the prairies, in the tundra regions of the world (Benson and Sturm, 1993) and in most alpine regions (Vionnet and others, in press). Wherever there is blowing snow, barchans, snow dunes, sastrugi and large drifts develop (Cornish, 1902; Seligman, 1936; Moss, 1938; Lied, 1963; Doumani, 1967; cf. Fahnestock and others, 2000, for megadunes). Even on sea ice, where snow plays an important role in the thermal and mass balance of the ice (Maykut and Untersteiner, 1971), a wide range of blowing-snow features can be found, including drifts that form in the lee of ice ridges (Sturm and others, 2002).

Benson (1982), examining blowing snow in the tundra regions of northern Alaska, USA, partitioned incoming snowfall $(P)$ into two components (Fig. 1): snow trapped locally by tundra vegetation $\left(P_{\mathrm{t}}\right)$ and snow transported laterally by wind $\left(P_{\mathrm{r}}\right)$. He identified this latter component as the source of the wind-blown flux of snow $(Q)$, which he further subdivided into: (1) a sublimation flux $\left(Q_{\mathrm{e}}\right)$ that is returned to the atmosphere during transport; and (2) a drift flux $\left(Q_{\mathrm{d}}\right)$ that is deposited in depressions in the landscape or in the lee of obstructions, such as houses, rocks and fences. In fact, $P_{\mathrm{t}}$ is just a small and local version of $Q_{\mathrm{d}}$, with the first few snowfalls and wind events of the winter 'filling' the micro-drift traps created by tundra tussocks and hummocks (Fig. 1b). Larger drift traps like gullies (Fig. 1c) and snow fences (Fig. 1d) can become filled with snow as well if $Q_{d}$ is sufficiently large. With minor modifications, the partitioning of Benson (1982) is applicable to blowing snow in alpine regions and on sea ice, glaciers and ice caps, and highlights two areas of blowing snow that are of interest: the windblown flux and resulting drift deposits.

Historically, there has been considerable interest in establishing the magnitudes of, and relationships between, $Q, Q_{\mathrm{e}}$ and $Q_{\mathrm{d}}$ (Takeuchi, 1980; Schmidt, 1986; Tabler and others, 1990; Pomeroy and Gray, 1995). Such relationships are essential in designing and planning structures where there is drifting snow. For example, while sublimation loss $\left(Q_{\mathrm{e}}\right)$ during blowing snow has been widely discussed (Schmidt, 1972; Van den Broeke, 1997; Bintanja, 2001; Box and Steffen, 2001; King and others, 2001; Déry and Yau, 2002; Zhang and others, 2004), a consensus on how to measure $Q_{\mathrm{e}}$ or what values to use remains elusive. Similarly, saltation and turbulent suspension, the two mechanisms that produce $Q$, have been the subject of many studies (for summaries see Tabler and others, 1990; Pomeroy and Gray, 1995), yet uncertainty remains as to which mechanism transports more snow. The final and by far the smallest body of studies concern $Q_{\mathrm{d}}$. This term, essentially the snow deposition rate, is important because of its relationship to mass balance, but it is also important because it produces drifts, which are of interest in their own right. Drifts play a significant role in the ecology, hydrology and human commerce of arctic and alpine areas. Late-lying drifts are sources of water long after most snow has melted from an area (Cooley and others, 1981), thereby nurturing snow-bed communities (Walker and others, 2001; Björk and Molau, 2007) and supplying water to streams that might otherwise go dry. Drifts accelerate erosion (see nivation hollows: Lewis, 1939; Henderson, 1956; Thorn, 1976) and are important in the landscape evolution of arctic and alpine regions, and drifts have been implicated as a mechanism in the development of the Pleistocene ice sheets (Williams, 1978). Drifts are important contributors to thermokarst (Hinkel and Hurd, 2006), a timely topic in a period of climate warming. And of course, drifts clog motorways and cost hundreds of millions of dollars a year to clear.

To date, methods employed to quantify $Q$ (Table 1 ) have included: (1) capturing saltating (and in some cases suspended) snow grains in small-volume traps, usually arrayed at several heights; (2) trapping saltating snow in relatively small (up to $1 \mathrm{~m}$ ) trenches or ditches; (3) counting 

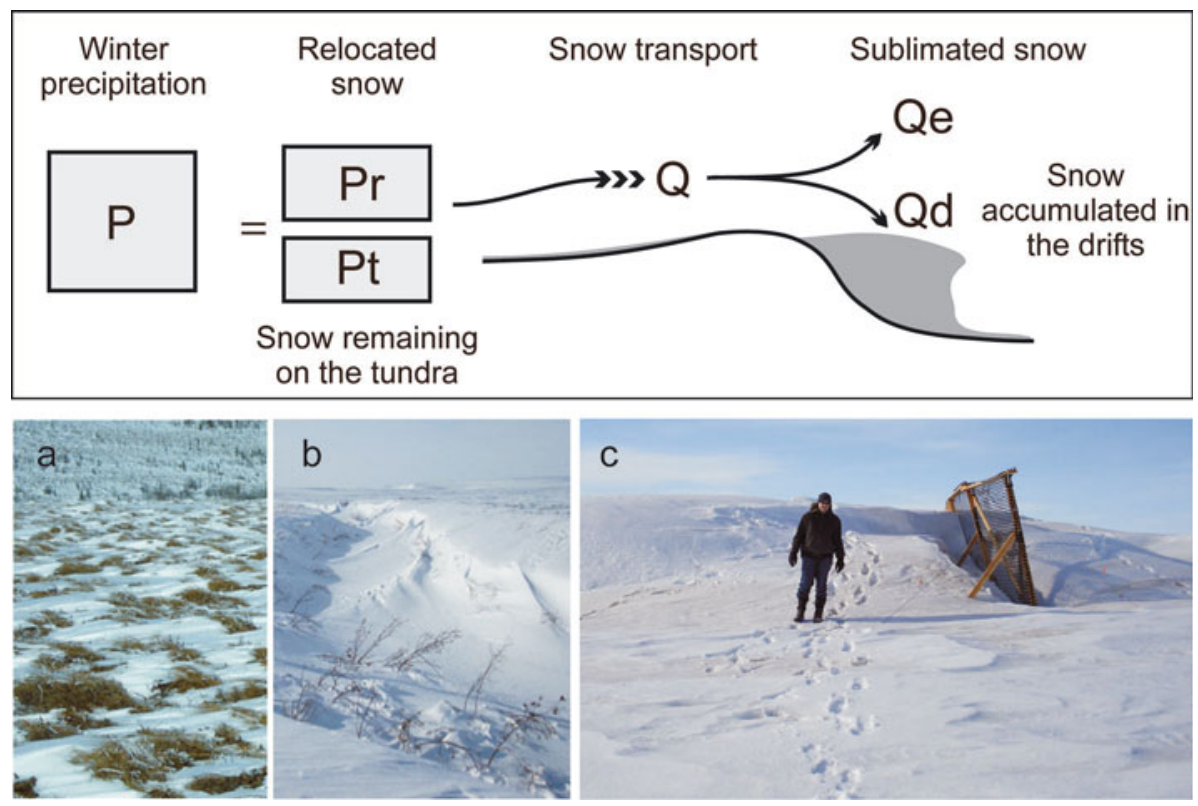

Fig. 1. (a) Benson's (1982) partitioning of the wind-blown flux of snow. (b) Tundra tussocks have trapped $P_{\mathrm{t}}$. (c) A gully and (d) a snow fence have trapped $Q_{\mathrm{d}}$. The gully is not full, but the fence, with the wind blowing from right to left, appears to have reached its equilibrium profile.

saltating grains using optical or acoustical sensors (Chritin and others, 1999; Cierco and others, 2007); and (4) accumulating saltating and suspended snow grains in large-volume traps, natural or man-made (i.e. snow fences or berms).
Traps and sensors have been deployed singly and in multiple arrays over a wide range of heights $(0.15-5 \mathrm{~m})$, making cross-experiment comparisons difficult because blowing-snow density is a strong function of height. Deployment times have ranged from minutes, in the case

Table 1. Studies that have quantified the flux of blowing snow $(Q)$

\begin{tabular}{|c|c|c|c|c|c|}
\hline Study & Location & Method & $\begin{array}{c}\text { Height } \\
\text { m }\end{array}$ & Observation period & $n$ \\
\hline Dingle and Radok (1961) & Antarctica & $\begin{array}{l}\text { Mellor traps and saltation traps at } \\
\text { nine levels }\end{array}$ & $0-4$ & $2-30 \mathrm{~min}$ & 18 \\
\hline Komarov (1963) & Russia & Probably collectors & $0-2$ & Not specified & 92 \\
\hline Kobayashi (1972) & Japan & $\begin{array}{l}\text { Open box traps; small and } \\
\text { large trenches }\end{array}$ & Near surface & $1-4 \min$ & 36 \\
\hline $\begin{array}{l}\text { Dyunin and Kotlyakov } \\
(1980)^{*}\end{array}$ & Western Siberia & Snow collectors & $0-2$ & Not specified & Not specified \\
\hline Takeuchi (1980) & Japan & Bag traps & $0-2$ & Hour & 6 \\
\hline Kikuchi (1981) & $\begin{array}{l}\text { Wind tunnel, } \\
\text { Hokkaido, Japan }\end{array}$ & Box collector and laser profiler & $0-0.15$ & Not specified & 52 \\
\hline Berg (1986) & Colorado, USA & Particle counters & 0.85 & $60 \mathrm{~min}$ (average) & 4157 \\
\hline Mellor and Fellers $(1986)^{\dagger}$ & Antarctica & Snow collectors & $0-5$ & Not specified & Not specified \\
\hline Schmidt (1986) & Wyoming, USA & Mesh drift flux trap & $0-0.5$ & Many runs, each $\sim 10 \mathrm{~min}$ & 15 \\
\hline Meister (1987) & Swiss Alps & $\begin{array}{l}\text { Mellor traps; Schmidt optical } \\
\text { sensors. Glass funnel }\end{array}$ & $0-4$ & $173 \mathrm{~min}$ (average) & 75 \\
\hline Pomeroy (1988) & $\begin{array}{l}\text { Saskatoon, } \\
\text { Saskatchewan, Canada }\end{array}$ & Particle counters at several heights & $0-2$ & Not specified & 146 \\
\hline Wendler (1989) & Antarctica & $\begin{array}{l}\text { Improved photoelectric particle } \\
\text { counter }\end{array}$ & 0.38 & $60 \mathrm{~min}$ & 107 \\
\hline Tabler and others (1990) & Prudhoe Bay, Alaska, USA & A $\quad$ Snow fence & $0-5$ & Season & 4 \\
\hline Pomeroy and Gray $(1995)^{\ddagger}$ & Canadian Prairies & Model & $0-5$ & Not applicable & Not applicable \\
\hline Font and others $(1998)^{\S}$ & Spain & $\begin{array}{l}\text { Collector columns and traps at } \\
\text { six levels }\end{array}$ & $0-2$ & $<1$ day & 13 \\
\hline Doorschot and others (2004) & Swiss Alps & Particle counter and snow bags & $<0.3$ & 14 hours over 1 year & 136 \\
\hline Gordon and others (2010) & Nunavut, Canada & $\begin{array}{c}\text { Mesh snow traps at five heights and } \\
\text { camera system }\end{array}$ & $0-0.9$ & Continuous & Not specified \\
\hline
\end{tabular}

*Individual data not provided.

†Data primarily from Dingle and Radok (1961).

Model.

${ }^{\S}$ Data reported in incompatible units. 


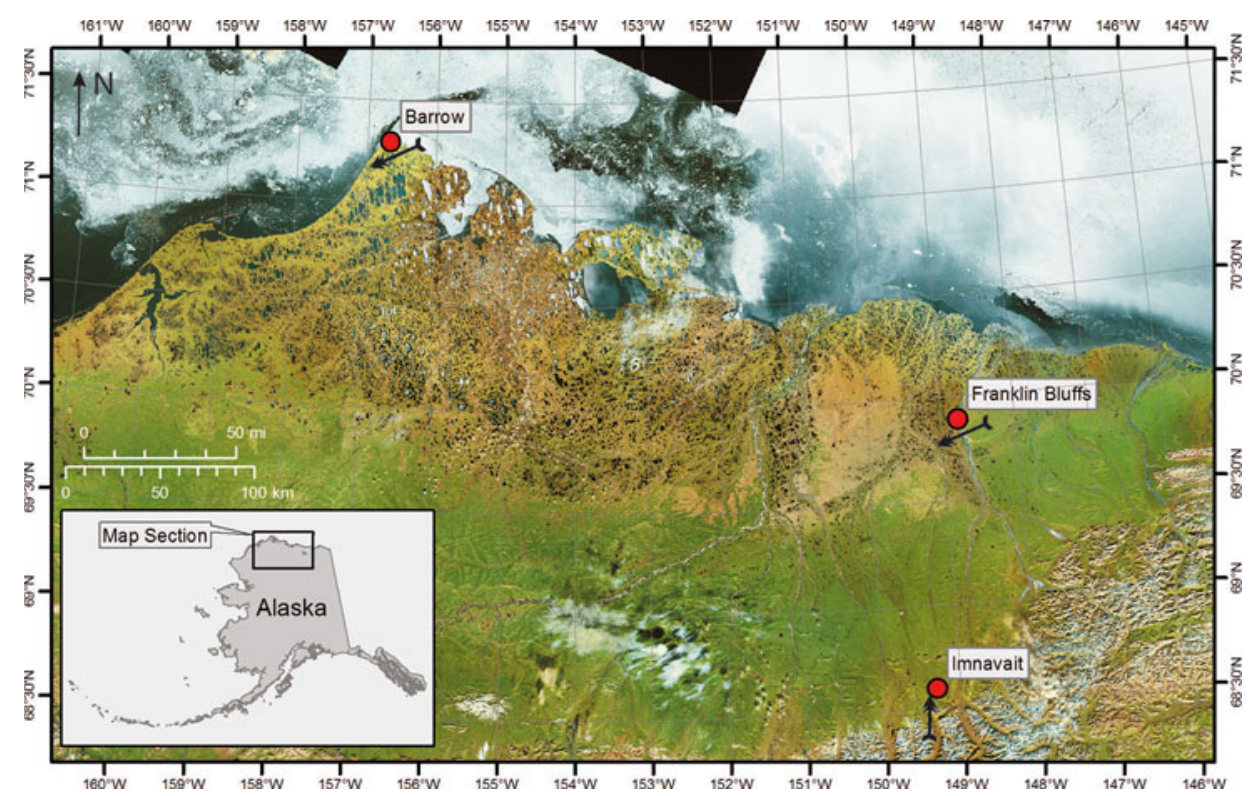

Fig. 2. The North Slope of Alaska, showing the location of the three snow fences used in the study and the direction (black arrows) of the prevailing winter winds as inferred from snow features and/or recorded by anemometers.

of small-volume traps and boxes, to months for large traps like snow fences, adding to cross-comparison difficulties. In addition, the efficiency of some traps is known to be $<50 \%$ (Font and others, 1998) and virtually no measurements (perhaps with the exception of those obtained using method 4) include the complete suspended load. To complicate matters further, wind speeds associated with fluxes have been measured at heights ranging from 1 to $11 \mathrm{~m}$ above the ground, making it difficult to compare the fluxes as a function of wind speed. Lastly, while some of the measurements (method 3) can be made continuously, these measurements require knowing the particle mass distribution in order to convert number fluxes into mass fluxes. In light of all this, it is not surprising that more than nine different functional equations relating $Q$ to wind speed ( $w$ ) have been proposed (Takeuchi, 1980; Tabler and others, 1990; Pomeroy and Gray, 1995).

In this study we use method 4 . To our knowledge, snowfence drift traps have been used only once before (Tabler and others, 1990) for computing $Q$. Using snow-fence drift traps requires establishing a relationship between $Q$ and $Q_{\mathrm{d}}$ as well as assessing the trapping efficiency of snow fences (Tabler and others, 1990). In principle, $Q_{\mathrm{d}}$ is simply $Q$ minus $Q_{\text {e }}$ (cf. Fig. 1 and Benson, 1982), but because large drift deposits are the cumulative result of multiple drift events produced by variable winds (including lulls) and snow conditions, the functional relationship between drift volume and $Q$ is complicated. To address this deficiency, we instrumented three snow fences in Arctic Alaska (Fig. 2) with lines of sonic depth sounders on the downwind side of each fence (Fig. 3). For 3 years, we observed the build-up of drifts, wind speed, air temperature, relative humidity and snowfall. We coupled the snow depth time series with periodic drift surface profile surveys from which we were able to develop a relationship between the depth readings and the drift volume. This method allowed us to compute $Q_{\mathrm{d}}$ for 36 distinct drift events.

As we will show, the new results are reasonably consistent with the previous measurements (Table 1), and the old and new data combined define a cloud for which we develop upper and lower bounding equations. We suggest that these bounds, rather than a single equation, are best used when attempting to estimate the drift flux for a given set of wind and snow conditions.

\section{FIELD AREA AND METHODS}

The North Slope of Alaska (Fig. 2) and the adjacent Brooks Range foothills are tundra. Snow stays on the tundra for 8-10 months each year and wind is ample. Consequently, there is a lot of blowing snow. This has produced a rich history of studies on this topic (Black, 1954; Benson, 1982; Benson and Sturm, 1993; Li and Sturm, 2002). In general, the prevailing winter winds are from the northeast or east along the Arctic coast from Barrow to Prudhoe Bay. Monthly mean wind speeds average 3.5-5.4 $\mathrm{m} \mathrm{s}^{-1}$; occasional peak wind speeds can reach $>20 \mathrm{~m} \mathrm{~s}^{-1}$. Inland near the Brooks Range, monthly mean wind speeds are slightly lower $\left(\leq 4.2 \mathrm{~m} \mathrm{~s}^{-1}\right.$; Olsson and others, 2002), but strong winds from the south can originate as katabatic flows down the many northoriented valleys of the Brooks Range. These katabatic winds readily exceed $20 \mathrm{~m} \mathrm{~s}^{-1}$.

The location of the transition between southerly and easterly winds, which undoubtedly varies from one winter to the next, can be identified by drift orientation. During winters that we have traversed from Brooks Range to the coast (1994, 1995, 1996, 2002, 2004, 2006, 2010), the transition was located approximately at the northern edge of rolling uplands where the hills give way to the coastal plain (Fig. 2). While difficult to verify, our experience suggests that just north of this transition zone $\left(\sim 69^{\circ} 30^{\prime} \mathrm{N}\right)$, a high-wind and blowing-snow zone occurs, where snow cover is noticeably thinner and denser than near the coast or further inland, a fact confirmed by synthetic aperture radar (SAR) satellites (Li and Sturm, 2002). In general, snow depth and snow water equivalent (SWE) decrease from inland to the coast (SWE values of 15-20 cm near the foothills to $6-12 \mathrm{~cm}$ near the coast; Liston and Sturm, 1998), while bulk snow density and the prevalence of wind slabs increase (Sturm and Liston, 2003). 

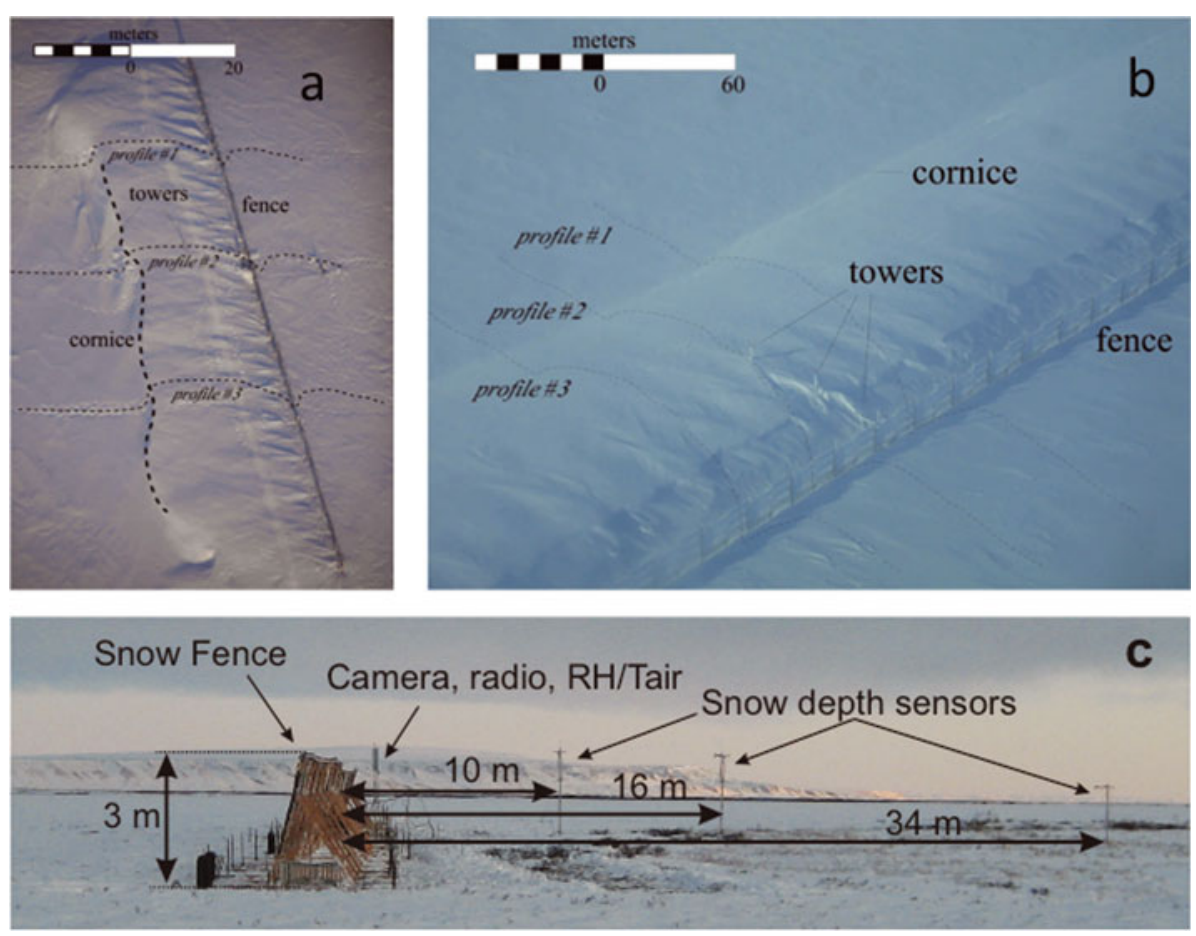

Fig. 3. The three snow fences used in the study: (a) Imnavait, (b) Barrow, (c) Franklin Bluffs.

We monitored snow-fence drift development in each of the three wind regimes: (1) Imnavait - southerly flow, intermittent moderate winds; (2) Barrow - easterly flow, steady moderately strong winds (Table 2); (3) Franklin Bluffs - northeasterly strong winds. At Imnavait Creek, just north of the Brooks Range, we built an east/west-oriented fence similar to the original sloped-fence design proposed by Tabler (2003). The fence trapped snow driven by southerly winds. At Barrow, we used an existing north/south-oriented fence, designed to protect a local subdivision. At Franklin Bluffs, $50 \mathrm{~km}$ inland from the coast, in the high-wind and drift zone, we built a north/south-oriented wood and plastic fence based on the Tabler (2003) design (Fig. 3c).

Three sonic distance sounders (Campbell SR-50s) were placed on towers located along a flowline on the leeward side of each fence. The distance from the fence and the sensor height (Table 2) were based on the expected drift profile. An anemometer was affixed to the top of the fence. At Barrow, a webcam was mounted on the fence, aimed at the downwind drift. At the Imnavait and Franklin Bluffs fence sites, we erected additional meteorological towers adjacent to, but outside of, the influence of the fence, where a second sonic sounder was used to monitor the natural snow depth. At Barrow, we used data from a meteorological tower $\sim 3 \mathrm{~km}$ from the fence (cf. http://www.ipysnow.net/Data.html) for this purpose. Wind speed, wind direction and temperature were recorded at the fence and at adjacent meteorological sites every $10 \mathrm{~min}$. Additionally, each of the fence sites was within $30 \mathrm{~km}$ of a site with a $10 \mathrm{~m}$ weather tower as well as a Wyoming shield precipitation gauge against which we could check the local conditions. Unless otherwise specified, all wind speeds are referenced to $10 \mathrm{~m}$ height.

Periodically the fences were visited and surface elevation profiles of the drifts on both sides of the fence were surveyed using a differential real-time corrected GPS (DGPS; Trimble 5700, Trimble R8). Horizontal and vertical positions recorded by these systems have an accuracy of $\pm 2 \mathrm{~cm}$. Pre-snow-cover DGPS surveys were used to determine the

Table 2. Snow fences used in this study

\begin{tabular}{|c|c|c|c|}
\hline & Imnavait & Barrow & Franklin Bluffs \\
\hline Location & $68.60^{\circ} \mathrm{N}, 149.3096^{\circ} \mathrm{W}$ & $71.30^{\circ} \mathrm{N}, 156.670^{\circ} \mathrm{W}$ & $69.89^{\circ} \mathrm{N}, 148.7790^{\circ} \mathrm{W}$ \\
\hline Elevation (ma.s.I.) & 913 & 5 & 77 \\
\hline Material & Trusses w/Resinet SF50 & Vertical wooden slats & Trusses w/Resinet SF50 \\
\hline Porosity (\%) & 55 & 54 & 55 \\
\hline Height (m) & 2.4 & 4.0 & 3.0 \\
\hline Length $(\mathrm{m})$ & 71 & 915 & 100 \\
\hline Orientation & east to west & south to north & northwest to southeast \\
\hline Prevailing wind & south, southeast & east, west & northeast, southwest \\
\hline Sonic sensors (m) & $3,8,15 \mathrm{~m}$ & $3,10,20 \mathrm{~m}$ & $10,16,34 \mathrm{~m}$ \\
\hline Period of record & 2008-11 & 2007-11 & 2009-11 \\
\hline Profile surveys & 6 & 13 & 2 \\
\hline
\end{tabular}


Table 3. Duration of wind events in hours (top) and percentage (bottom) from October to April

\begin{tabular}{lccccc}
\hline Location & Period & $0-8 \mathrm{~m} \mathrm{~s}^{-1}$ & $8-17 \mathrm{~m} \mathrm{~s}^{-1}$ & $17-25 \mathrm{~m} \mathrm{~s}^{-1}$ & Missing \\
\hline Barrow & $2007-11$ & 14534 & 3948 & 10 & 1884 \\
Imnavait & $2007-11$ & 18336 & 1966 & 38 & 36 \\
Franklin & $2009-11$ & 7505 & 1413 & 89 & 1169 \\
Barrow & $2007-11$ & $79 \%$ & $21 \%$ & $0.1 \%$ & $9 \%$ \\
Imnavait & $2007-11$ & $90 \%$ & $10 \%$ & $0.2 \%$ & $0 \%$ \\
Franklin & $2009-11$ & $83 \%$ & $16 \%$ & $1.0 \%$ & $11 \%$ \\
\hline
\end{tabular}

local topography and the position of the towers and sonic sounders. Winter drift volumes $\left(\mathrm{m}^{3}\right.$ per lineal meter of fence, denoted $\mathrm{m}^{3} \mathrm{~m}^{-1}$ ) were calculated as the difference between snow and ground surface elevations. Particularly in the case of the Barrow fence, the drift surface often appeared fluted, so multiple profile lines perpendicular to the fence were measured to ensure an accurate surface profile. Upon comparison, however, we found little difference in drift volume from one profile to the next, even when fluting was present. During surveys, drift density was sampled in snow pits and with a Federal snow corer. Owing to the hardness and depth of the drifts, we found we could rarely penetrate to the drift base with the corer, so the resulting values of density provide at best only rough bounds on the drift snow density. We have relied on the results of Tabler (1980) along with our measurements in setting density values. Drift stratigraphy was observed in deep snow pits cut into the Imnavait drift in 2009, 2010 and 2011 and in the Franklin Bluffs drift in 2010 and 2011. The Barrow drift was generally too hard and difficult to excavate for similar snow-pit observations.

We used the sonic sounder records to identify snow deposition events (SDEs). First, the records were filtered to remove spikes associated with falling and blowing snow. Next, using the rules shown in Figure 4, drift events were separated from snowfall events and then quantified (duration, change in drift height, associated wind speed). In all, 36 such events were identified (Table 3).

\section{RESULTS}

\section{Wind}

As expected, the three fence sites exhibited different wind regimes (Fig. 5). Barrow had the highest frequency of snoweroding winds ( $>8 \mathrm{~m} \mathrm{~s}^{-1}$ from the east-northeast to east), but virtually no winds in excess of $15 \mathrm{~m} \mathrm{~s}^{-1}$. In addition, a small but significant number of backing events (winds from the west) pushed snow back through the fence from the lee side (in 2011), which resulted in the peak of the drift forming on the east rather than the west side of the fence that year. The average wind speeds at Franklin Bluffs and Imnavait Creek were not as high as at Barrow, but the peak winds at these sites were higher and high winds occurred more frequently than at Barrow. At Imnavait, high winds $\left(>15 \mathrm{~m} \mathrm{~s}^{-1}\right)$ tended to be bimodal, with one mode from the south blowing across the fence and another from the west blowing parallel to the fence. During westerlies, little transport occurred into or out of the drift, but the off-axis wind direction caused fluting. Table 3 summarizes the occurrence frequency of low, medium and high winds for the three sites.

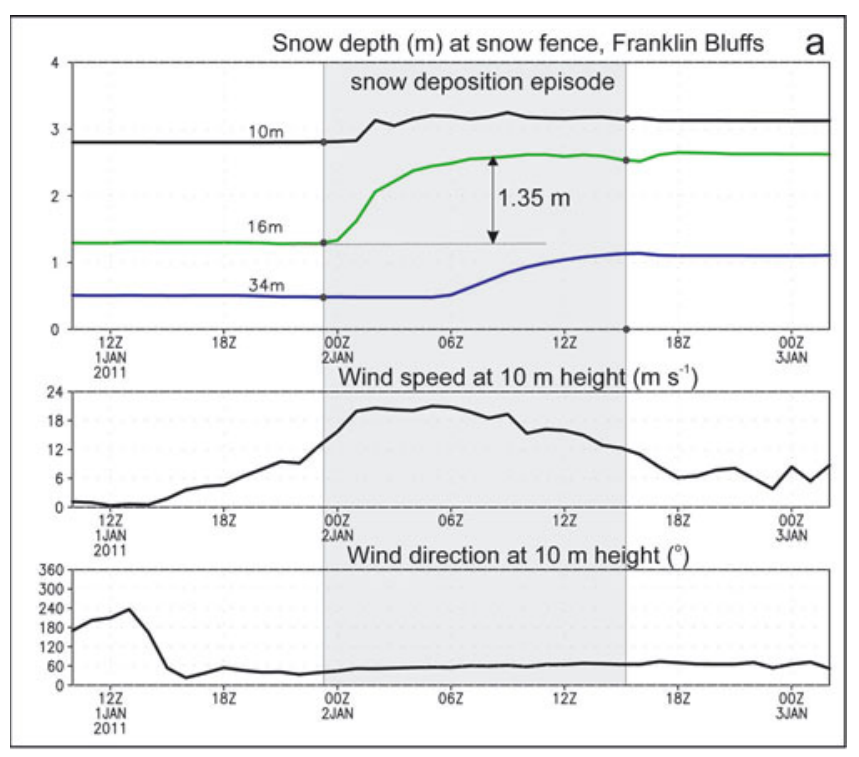

Plot measurements of snow depth at each sonic sensor, $10 \mathrm{~m}$ height wind speed and direction

Select events with change in snow depth greater than $0.3 \mathrm{~m}$
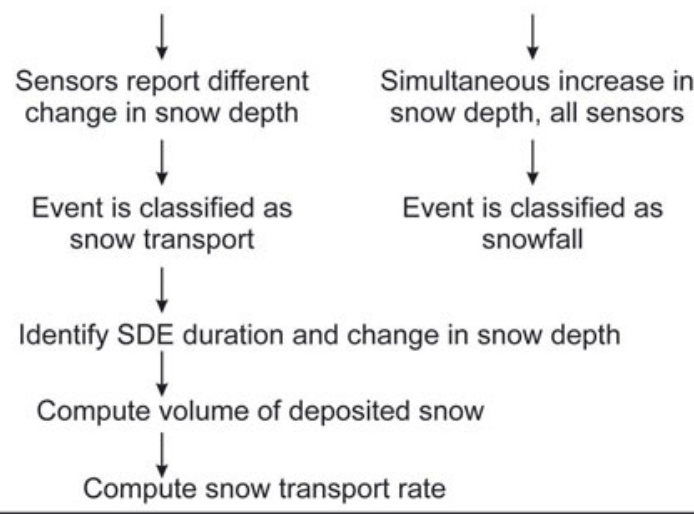

Fig. 4. (a) Sample sonic sounder and weather records and (b) the rubric used to identify snow deposition events from this and other records.

\section{Drift profiles}

From our drift surveys we were able to identify three (Fig. 6a and b) of the four stages of drift growth identified by Tabler (2003). Initially, snow collected on both sides of a fence in low $(<0.5 \mathrm{~m})$ lens-shaped deposits (stage 1$)$. Next, the drift on the leeward side of the fence increased in height and began to extend downwind, eventually developing a slip face that was often corniced due to rotor winds (stage 2; see http:// vimeo.com/9603170). In our study, these slip faces had average slopes of 55 . In 2008, 2010 and 2012, the Imnavait drift never grew beyond this stage, but in 2009 and 2011 it did. Next, with sufficient flux, the downwind side of the slip face filled and the drift assumed a streamlined profile (stage 3). Stage 4, called the equilibrium profile by Tabler (1975), was achieved in only a few cases where the drifts reached the maximum snow retention capacity of the fence.

The drifts from the three fences had similar profiles despite differences in fence height, fence design (Table 2) and wind regime (Table 3). Tabler (1980) proposed fitting lee-side drift profiles with a fifth-order polynomial in order 


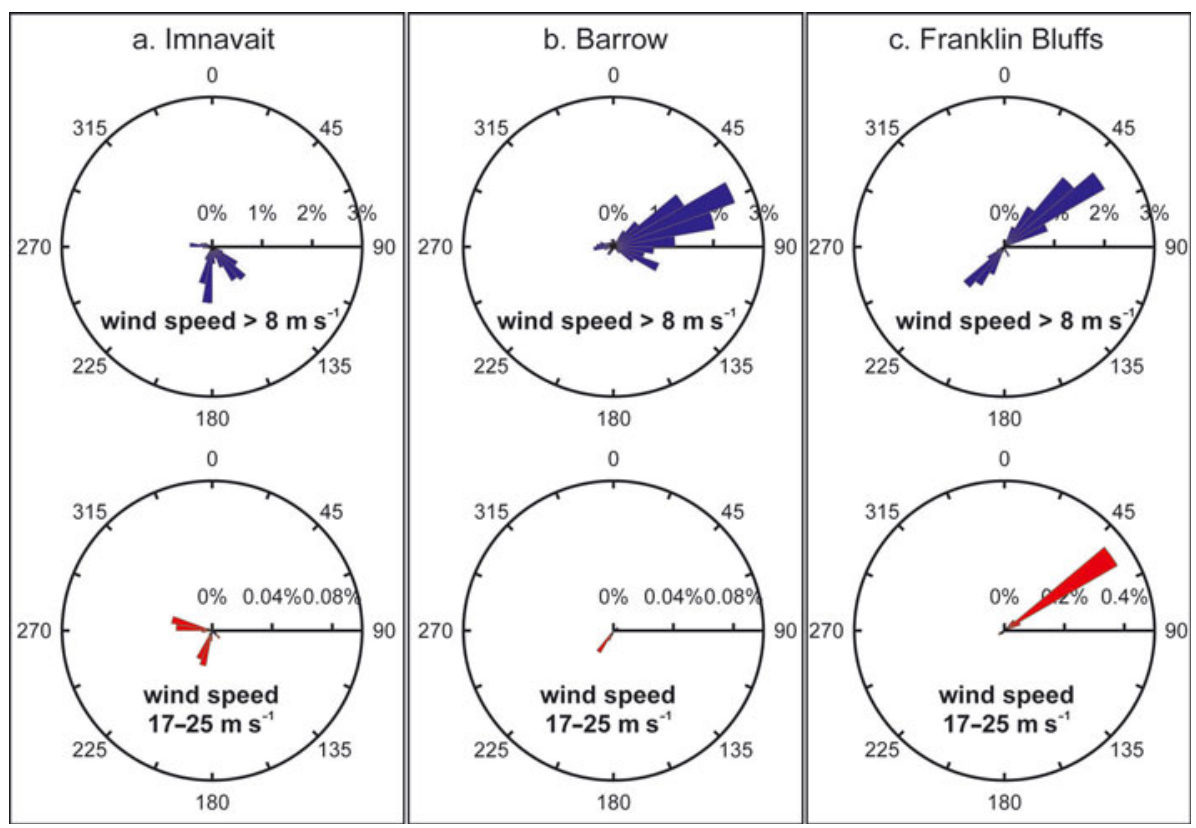

Fig. 5. Winter wind speeds and directions at the three snow fences for the period 2008-11. See also Table 3.

to determine drift volume. He used a separate linear equation for the windward drift. However, the similarity of drift profiles (windward plus leeward) to Gaussian curves suggested that the volume might be more efficiently represented using a logistic equation because in cumulative form logistic curves are Gaussian. Logistic curves have been used for more than 100 years to describe population growth in a limited-resource environment. The rate of increase of a population at any given time $(t)$ is proportional to the number of individuals alive at that time $(N(t)$ : the reproductive stock), plus a term to account for resource limitations. As the population approaches $N_{\max }$ the system's maximum carrying capacity, the rate of the population increase must decline to zero:

$$
\frac{\mathrm{d} N}{\mathrm{~d} t} \propto N(t)\left\{1-\frac{N(t)}{N_{\max }}\right\}
$$

By analogy, if drift volume $(V)$ is integrated along a flowline perpendicular to the fence (denoted by $x$, where $x=0$ is the upwind edge of the drift and $d$ is the $x$-coordinate of the
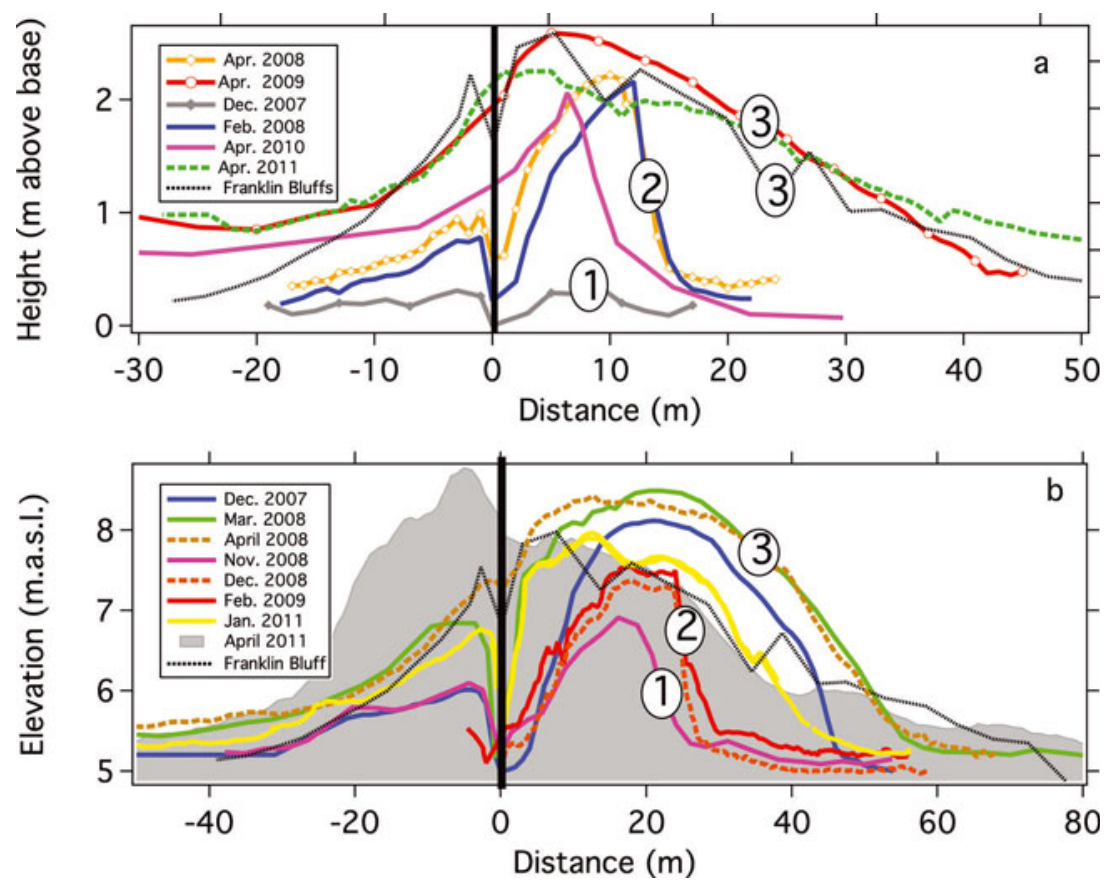

Fig. 6. (a) Profiles of the Imnavait drift showing three of the four stages of development identified by Tabler (2003). Note that in 2008 and 2010, the Imnavait drift never grew beyond stage 2. (b) Cross profiles of the Barrow drift, again showing three stages of development. The Franklin Bluffs profile has been added to both (a) and (b), downscaled appropriately to match the Imnavait drift profiles (which are smaller). The Franklin Bluffs drift is longer in a downwind direction than the Barrow drift, probably because it was deposited by stronger winds, but it is comparable with the stage 3 Imnavait profile, which was also the product of higher winds. The April 2011 profile (shaded gray) for Barrow shows the effect of westerly winds pushing snow back through the fence to the (normally) windward side. 


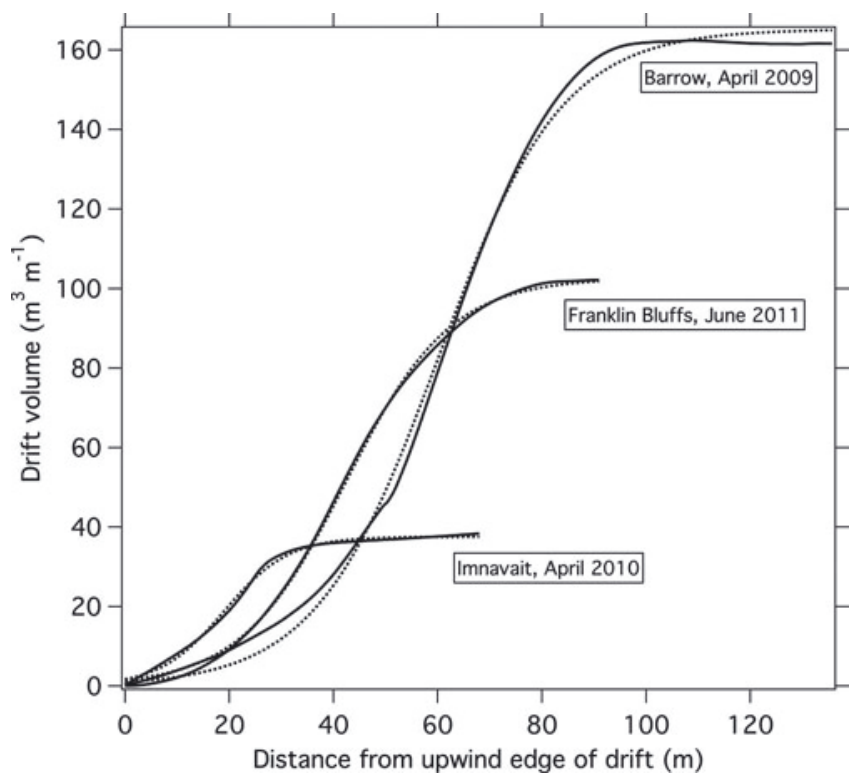

Fig. 7. Surveyed cumulative drift volume curves (solid) compared with the results of Eqn (3) (dotted). In those cases where a deep $\mathrm{v}$-shaped moat was present at the fence, a small jog appears in the measured curve (Barrow, April 2009 at $x=50 \mathrm{~m}$ ). Fitting parameters $\left(V_{\text {total }}, d\right.$ and $\left.s\right)$ are given in Table 4.

snow fence), the volume will increase downwind at first slowly, then more rapidly as the drift depth increases. In this proximal part of the drift, blowing snow is abundant, so the drift volume increase is only limited by trapping capacity. As the distal portion of the drift is approached, the trapping capacity peaks, but the rate of increase in the cumulative volume declines and eventually drops to zero because the resource (snow) has been fully depleted. The governing differential equation for this spatial process describing snowdrifts is similar to Eqn (1):

$$
\frac{\mathrm{d} V}{\mathrm{~d} x}=\frac{1}{S} V(x-d)\left\{1-\frac{V(x-d)}{V_{\text {total }}}\right\}
$$

where $s$ is a fitting parameter, $V_{\text {total }}$ is the total volume $\left(\mathrm{m}^{3} \mathrm{~m}^{-1}\right)$ of the drift and the equation is framed in terms of distance $(x)$ rather than time $(t)$, which is the independent variable in Eqn (1). When Eqn (2) is integrated, the result is

$$
V_{x}=\frac{V_{\text {total }}}{1+\mathrm{e}^{\left\{-\left(\frac{x-d}{s}\right)\right\}}}
$$

Equation (3) is skilled at fitting a wide range of drift shapes (Fig. 7), including drift stages 1-4 (cf. Fig. 6). It also encompasses both the upwind and downwind segments of the drift, making it potentially easier to use than Tabler's approach (1980). The fitting parameters ( $V_{\text {total }} d$ and $s$ ) for all 21 measured profiles are listed in Table 4, with representative curve fits for a selection of volume curves shown in Figure 7.

\section{Snow deposition events}

SDEs were defined as periods of blowing snow that lasted $>2$ hours, separated from other periods by at least 2 hours of calm. To be counted as an SDE, an event had to produce

\begin{tabular}{|c|c|c|c|c|c|c|c|c|}
\hline \multirow[t]{2}{*}{ Survey date } & \multirow{2}{*}{$\begin{array}{c}\text { Drift peak } \\
\text { m }\end{array}$} & \multirow{2}{*}{$\begin{array}{l}\text { Drift volume } \\
\qquad \mathrm{m}^{3} \mathrm{~m}^{-1}\end{array}$} & \multicolumn{3}{|c|}{ Drift height } & \multicolumn{3}{|c|}{ Fitting parameters } \\
\hline & & & & & & $d$ & $S$ & $V_{\text {total }}$ \\
\hline Imnavait & & & at $3 \mathrm{~m}$ & at $8 \mathrm{~m}$ & at $15 \mathrm{~m}$ & & & \\
\hline 12 Dec 2007 & & & & & & 29.89 & 12.5 & 11.4 \\
\hline 2 Feb 2008 & 2.16 & 34.86 & 0.53 & 1.75 & 0.39 & 25.44 & 6.2 & 33.7 \\
\hline 23 Apr 2008 & 2.22 & 67.85 & 1.06 & 1.98 & 0.63 & 25.14 & 6.8 & 43.0 \\
\hline 22 Apr 2009 & 2.59 & 99.42 & 2.36 & 2.56 & 2.34 & 29.73 & 9.6 & 100.0 \\
\hline 1 Apr 2010 & 2.06 & 38.36 & 1.92 & 1.77 & 0.36 & 18.99 & 6.2 & 37.6 \\
\hline 20 Apr 2011 & 2.25 & 98.53 & 1.91 & 2.16 & 1.96 & 30.99 & 10.8 & 98.8 \\
\hline Average & 2.26 & 67.80 & 1.56 & 2.04 & 1.14 & 26.69 & 8.67 & 54.06 \\
\hline Barrow & & & at $3 \mathrm{~m}$ & at $10 \mathrm{~m}$ & at $20 \mathrm{~m}$ & & & \\
\hline 18 Dec 2007 & 2.92 & 99.85 & & 1.46 & 2.22 & 73.0 & 10.1 & 109.0 \\
\hline 5 Mar 2008 & 3.29 & 167.8 & & 3.23 & 2.97 & 68.3 & 13.8 & 174.3 \\
\hline 18 Nov 2008 & 1.71 & 59.2 & 0.55 & 1.31 & 1.41 & 54.2 & 12.4 & 62.0 \\
\hline 10 Dec 2008 & 2.17 & 58.2 & 0.53 & 1.92 & 2.57 & 54.8 & 11.3 & 59.5 \\
\hline 11 Feb 2009 & 2.34 & 64.6 & 2.16 & 2.46 & 2.32 & 56.6 & 11.3 & 68.2 \\
\hline 17 Mar 2009 & 3.93 & 169.2 & 3.15 & 3.70 & 3.63 & 62.9 & 10.5 & 170.7 \\
\hline 27 Apr 2009 & 3.88 & 151.6 & 3.12 & 3.66 & 3.44 & 60.2 & 11.8 & 165.2 \\
\hline 18 Apr 2010 & 3.99 & 216.7 & 0.87 & 2.87 & 3.94 & 79.6 & 16.7 & 230.2 \\
\hline 24 Nov 2010 & 1.51 & 43.4 & 1.18 & 1.18 & 1.61 & 59.4 & 6.8 & 44.2 \\
\hline 10 Jan 2011 & 2.75 & 113.0 & 2.08 & 2.59 & 2.59 & 64.8 & 12.3 & 120.7 \\
\hline 29 Mar 2011 & 2.85 & 166.7 & 2.86 & 2.64 & 2.43 & 59.7 & 13.2 & 166.1 \\
\hline 11 Apr 2011 & 3.56 & 180.9 & 2.87 & 2.63 & 2.41 & 61.8 & 13.6 & 177.5 \\
\hline Average & 2.94 & 128.78 & 1.94 & 2.54 & 2.65 & 63.36 & 12.21 & 133.77 \\
\hline Franklin Bluffs & & & at $10 \mathrm{~m}$ & at $16 \mathrm{~m}$ & at $34 \mathrm{~m}$ & & & \\
\hline 24 Apr 2010 & 3.23 & 183.10 & 3.31 & 3.15 & 2.15 & 55.1 & 15.12 & 181.73 \\
\hline 3 Jun 2011 & 2.62 & 90.10 & 2.53 & 1.87 & 0.86 & 42.4 & 10.06 & 102.62 \\
\hline Average & 2.93 & 136.60 & 2.92 & 2.51 & 1.51 & 48.75 & 12.59 & 142.18 \\
\hline
\end{tabular}

Table 4. Drift surveys and fitting parameters for Eqn (3) 
Table 5. Snow deposition events (SDEs) and hourly averaged weather data

\begin{tabular}{|c|c|c|c|c|c|c|}
\hline \multirow[t]{2}{*}{ Event number } & \multicolumn{2}{|c|}{ Deposition rate } & \multirow{2}{*}{$\begin{array}{l}\text { Wind at } 10 \mathrm{~m} \\
\qquad \mathrm{~m} \mathrm{~s}^{-1}\end{array}$} & \multirow{2}{*}{$\begin{array}{l}\text { Max. wind at } 10 \mathrm{~m} \\
\mathrm{~m} \mathrm{~s}^{-1}\end{array}$} & \multirow{2}{*}{$\begin{array}{c}\text { Relative humidity } \\
\%\end{array}$} & \multirow{2}{*}{$\begin{array}{l}\text { Air temperature } \\
{ }^{\circ} \mathrm{C}\end{array}$} \\
\hline & $\mathrm{m}^{-3} \mathrm{~m}^{-1} \mathrm{~h}^{-1}$ & $\mathrm{~kg} \mathrm{~m}^{-1} \mathrm{~s}^{-1}$ & & & & \\
\hline \multicolumn{7}{|l|}{ Imnavait } \\
\hline 101 & 0.235 & 0.029 & 8.6 & 10.0 & 63.9 & -5.0 \\
\hline 102 & 2.541 & 0.318 & 10.6 & 19.8 & 55.2 & -12.2 \\
\hline 103 & 0.626 & 0.078 & 11.5 & 22.4 & 56.0 & -4.7 \\
\hline 104 & 0.480 & 0.060 & 11.7 & 18.9 & 72.5 & -0.7 \\
\hline 105 & 1.781 & 0.223 & 13.6 & 19.2 & 79.4 & -1.4 \\
\hline 106 & 1.145 & 0.143 & 10.2 & 12.2 & 61.7 & -11.1 \\
\hline 107 & 1.696 & 0.212 & 9.0 & 13.4 & 61.8 & -6.9 \\
\hline 108 & 0.975 & 0.122 & 10.1 & 11.6 & 41.2 & -2.9 \\
\hline 109 & 1.295 & 0.162 & 11.0 & 12.4 & 72.3 & -13.1 \\
\hline 110 & 0.127 & 0.016 & 8.6 & 11.3 & 42.9 & -7.7 \\
\hline 111 & 0.622 & 0.078 & 11.8 & 13.7 & 95.0 & -7.0 \\
\hline 112 & 0.509 & 0.064 & 9.7 & 11.7 & 92.5 & -12.4 \\
\hline 113 & 3.702 & 0.463 & 11.0 & 16.0 & 66.7 & -10.3 \\
\hline 114 & 5.979 & 0.747 & 15.3 & 23.3 & 84.0 & -6.8 \\
\hline Average & 1.55 & 0.19 & 10.91 & 15.4 & 67.5 & -6.8 \\
\hline \multicolumn{7}{|l|}{ Barrow } \\
\hline 201 & 0.523 & 0.065 & 8.4 & 7.9 & - & -15.9 \\
\hline 203 & 1.073 & 0.134 & 8.9 & 6.0 & - & -14.8 \\
\hline 204 & 2.114 & 0.264 & 10.0 & 9.4 & - & -25.9 \\
\hline 205 & 1.560 & 0.195 & 12.7 & 13.4 & - & -22.1 \\
\hline 206 & 2.379 & 0.297 & 14.6 & 16.9 & - & -23.6 \\
\hline 207 & 0.915 & 0.114 & 11.9 & 10.3 & - & -13.3 \\
\hline 209 & 0.401 & 0.050 & 9.5 & 11.9 & - & -18.2 \\
\hline 210 & 0.487 & 0.061 & 13.0 & 12.9 & - & -17.1 \\
\hline 211 & 1.611 & 0.201 & 13.3 & 12.4 & - & -19.6 \\
\hline 212 & 1.577 & 0.197 & 13.0 & 15.7 & - & -24.0 \\
\hline 213 & 1.150 & 0.144 & 11.0 & 11.1 & - & -21.7 \\
\hline Average & 1.25 & 0.16 & 11.48 & 11.6 & - & -19.7 \\
\hline \multicolumn{7}{|l|}{ Franklin Bluffs } \\
\hline 301 & 3.923 & 0.490 & 14.2 & 18.0 & 95.2 & -8.3 \\
\hline 302 & 1.295 & 0.162 & 13.4 & 15.2 & 88.3 & -18.4 \\
\hline 303 & 1.561 & 0.195 & 14.1 & 15.9 & 88.6 & -18.4 \\
\hline 305 & 2.949 & 0.369 & 16.1 & 20.0 & 83.4 & -23.5 \\
\hline 306 & 1.565 & 0.196 & 15.8 & 20.8 & 82.7 & -24.0 \\
\hline 308 & 2.544 & 0.318 & 17.0 & 20.4 & 95.5 & -9.1 \\
\hline 309 & 2.590 & 0.324 & 18.1 & 21.0 & 81.7 & -25.3 \\
\hline Average & 2.35 & 0.29 & 15.53 & 18.8 & 87.9 & -18.1 \\
\hline \multicolumn{7}{|c|}{ Outliers due to biases in drift volume calculations } \\
\hline 307 & 0.47 & 0.06 & 17.7 & 20.0 & 89.4 & -16.1 \\
\hline \multicolumn{7}{|c|}{ No wind speed records } \\
\hline 202 & 1.59 & 0.20 & - & - & - & -16.6 \\
\hline 208 & 0.38 & 0.05 & - & - & - & -25.8 \\
\hline 304 & 0.22 & 0.03 & - & - & - & \\
\hline
\end{tabular}

$>0.3 \mathrm{~m}$ of change in snow depth at one or more sonic sounders (Fig. 4). We found 36 SDEs in total. This analysis indicated that while the shape and volume of the drifts seemed to be independent of fence characteristics (see Fig. 6), the growth patterns as defined by the nature of the SDEs at each site differed considerably (Table 5). These differences were driven by the local wind regimes (Fig. 5; Table 3). There was slow steady drift growth with many SDEs at Barrow, rapid drift growth from a few SDEs at Franklin Bluffs and an alternation between these two types of regime at Imnavait Creek, depending on the winter (Table 5). For example, at Barrow between 10 and 22 February 2010, constant and nearly continuous deposition occurred at the drift, yet after 12 days of transport the drift had increased in height by only $\sim 1 \mathrm{~m}$ (Fig. 8a). At Franklin Bluffs, where winds in excess of $17 \mathrm{~m} \mathrm{~s}^{-1}$ were five times more likely than at Imnavait Creek and ten times more likely than at Barrow (Table 3), just a few small SDEs occurred (four during two winters) but each winter there were several remarkably large SDEs (Fig. 8b). In one case, $2 \mathrm{~m}$ of snow were added to the drift in just 2 hours. At Imnavait, small (0.2-0.4 m) SDEs dominated the winters of 2008 and 2010 (Fig. 8c), while large SDEs (>1 $\mathrm{m} \mathrm{d}^{-1}$ deposition) occurred in the winters of 2009 and 2011. In the latter two winters, the drift reached its equilibrium profile (EP). These differences are reflected in the computed blowing-snow flux rates: the average blowingsnow flux rate at Franklin Bluffs was 1.9 times larger than the Barrow flux and 1.5 times larger than the Imnavait flux 


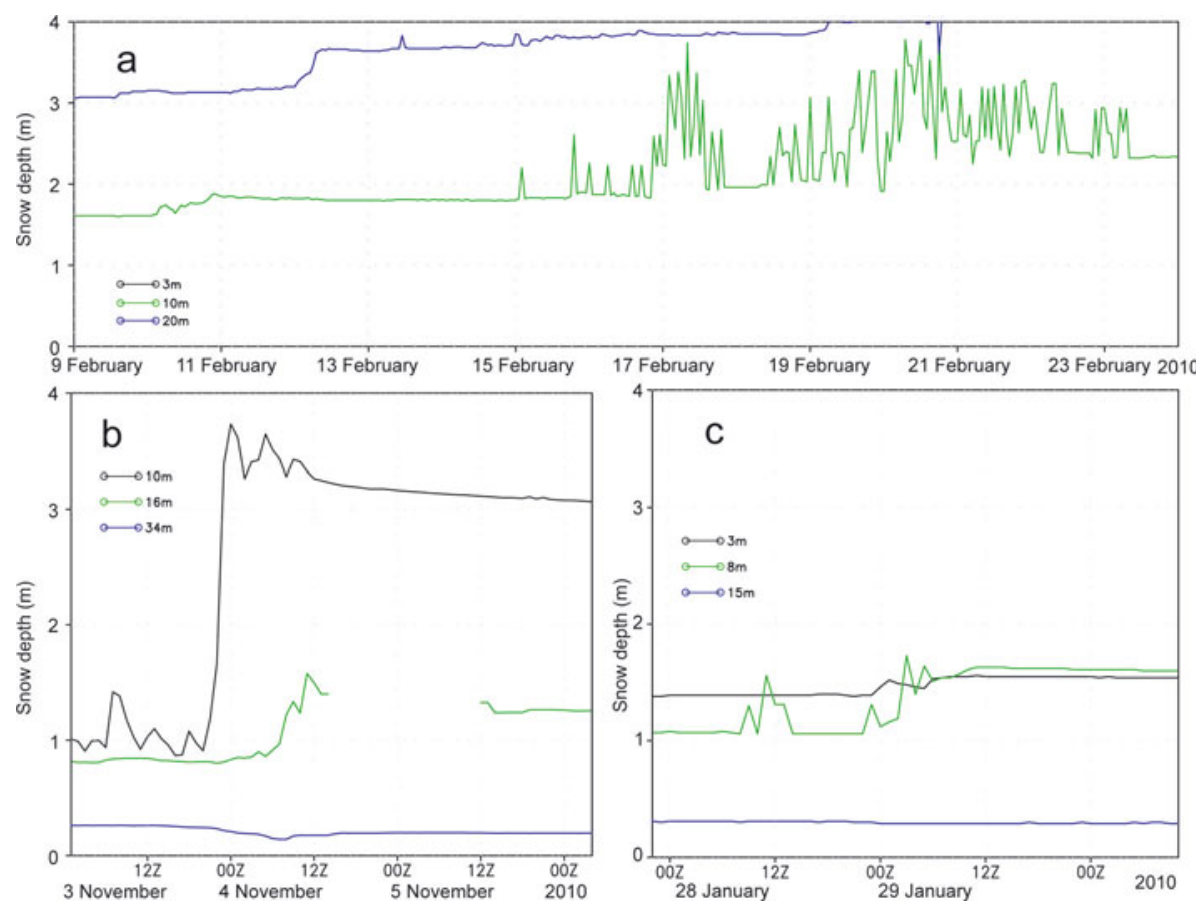

Fig. 8. (a) A long SDE at Barrow lasts $>10$ days but produces only $\sim 1 \mathrm{~m}$ change in depth. (b) A large SDE at Franklin Bluffs. (c) A small SDE at Imnavait Creek.

(Table 5). Similarly, differences in the nature of the SDEs at each fence are captured in the percent of the total drift volume accounted for by the identified SDEs (Table 6). In the case of Imnavait, this percentage varied from year to year and exceeded $60 \%$ in the years when the drift reached the EP. Often only $30 \%$ of the drift could be accounted for at Barrow, where the SDEs were small (and hence fell below our $0.3 \mathrm{~m}$ SDE cut-off). At Franklin Bluffs, where major windstorms built the drift, $>80 \%$ of the volume could be accounted for by the identified SDEs.

In only two cases during the study did we observe high winds but small (or no) SDEs. One case occurred on 18 October 2010, when the wind speed exceeded $19 \mathrm{~m} \mathrm{~s}^{-1}$ but there was only a $0.2 \mathrm{~m}$ increase in snow depth in the fence drift. The October date suggests that not enough snow had fallen yet to satisfy $P_{\mathrm{t}}$ (Fig. 1); consequently, the event was snow-supply limited. This seasonal bias may be reflected in the monthly distribution of SDEs: out of 36 SDEs, 31 occurred between November and February (Table 6), with almost one-third taking place in January. We interpret the differing drift growth patterns at the three fences to be evidence that wind regime, not snow depth or snow conditions (with the one exception noted above), is the primary control on drift growth on Alaska's North Slope, with snow supply playing a secondary role. For example, a comparison of end-of-winter snow depth at Imnavait Creek for 2007-11 with the 20 year mean shows that the snow depth varies about $\pm 30 \%$ from the mean from one winter to the next. While the years the fence was filled were winters with deeper snow, there was always snow available upwind of the fence even in the years when the snowpack was below average. In contrast, the occurrence of winds in excess of $17 \mathrm{~m} \mathrm{~s}^{-1}$ varied significantly, with strong winds being virtually absent in the years the fence did not fill, but notable wind runs of 16 and 21 hours (2009 and 2011, respectively) in the years the fence filled. It was the wind that clearly made the difference in the size of the drift.

\section{ANALYSIS: COMPUTING SNOW DEPOSITION FLUX RATES}

We calculated the snow deposition rate $\left(Q_{\mathrm{d}}\right)$ per meter of fence length by combining information from the sonic sounders, the drift profile surveys, the snow cores and the snow-fence trapping efficiency:

$$
Q_{\mathrm{d}}=\frac{\rho \Delta V}{\Delta t} \eta
$$

where $\rho$ is snow density $\left(\mathrm{kg} \mathrm{m}^{-3}\right), \Delta V$ is the change in drift volume during an SDE $\left(\mathrm{m}^{3} \mathrm{~m}^{-1}\right), \Delta t$ is the duration of the $\mathrm{SDE}$ and $\eta$ is snow-fence trapping efficiency (dimensionless). Because $\eta$ has not been well established and most of the SDEs occurred during the earlier stages (1 and 2) of drift development, when trapping efficiency tends to be high, $\eta$ was assumed to be 1 for purposes of calculation.

Equation (4) is easy to implement for a drift surveyed immediately before and after an SDE because then $\Delta V$ is well defined, but it was rare that our surveys bracketed these events. Instead we developed a statistical relationship

Table 6. Percent of drift volume accounted for by SDEs (top), and the monthly distribution of SDEs (bottom)

\begin{tabular}{|c|c|c|c|c|c|c|}
\hline \multicolumn{2}{|l|}{ Fence } & \multicolumn{2}{|l|}{ 2008/09 } & 2009/10 & \multicolumn{2}{|c|}{ 2010/11 } \\
\hline \multicolumn{2}{|c|}{$\begin{array}{l}\text { Imnavait } \\
\text { Barrow } \\
\text { Franklin Bluffs }\end{array}$} & $\begin{array}{l}75 \% \\
44 \%\end{array}$ & & $\begin{array}{l}28 \% \\
31 \% \\
94 \%\end{array}$ & \multicolumn{2}{|c|}{$\begin{array}{l}62 \% \\
30 \% \\
85 \%\end{array}$} \\
\hline \multicolumn{7}{|c|}{ SDEs per month (all sites) } \\
\hline 1 & 6 & 8 & 10 & 7 & 3 & 1 \\
\hline
\end{tabular}



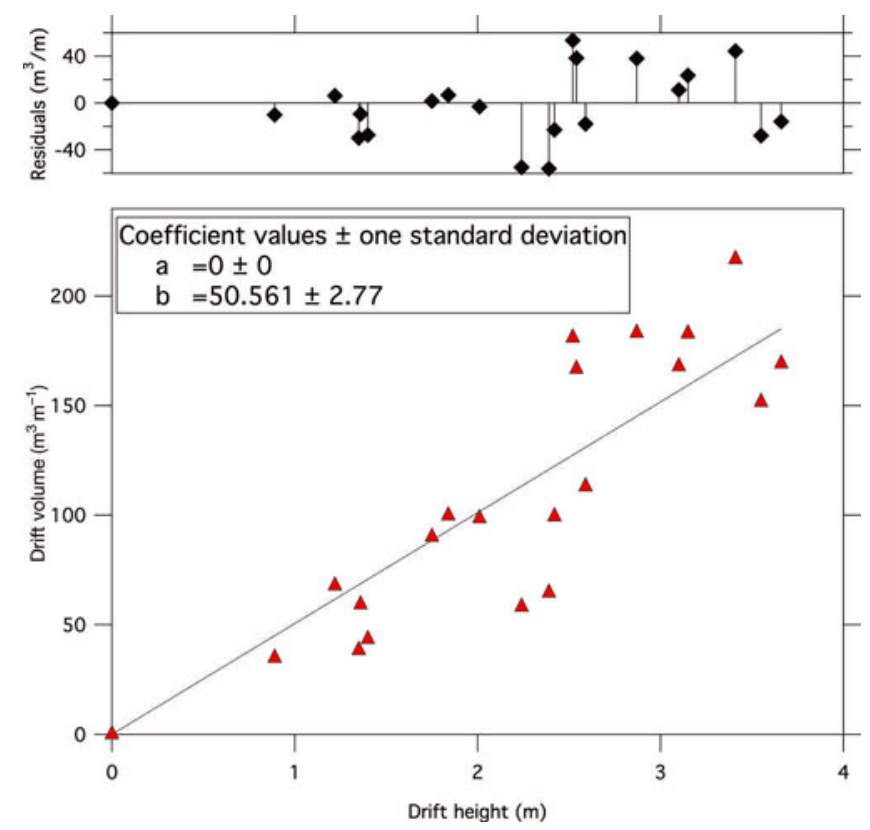

Fig. 9. Drift volume as a function of drift height, in this case as indicated by averaging the values from three sonic sounders taken at the time of each profile survey. Data are from all surveys at all fences and the regression has been forced through $(0,0)$. The residuals are shown at the top.

between drift height and volume (Fig. 9), using the profile surveys and the sonic sounder-derived heights from the time/ date of the surveys. This relationship allowed us to estimate the before and after SDE drift volumes when no profile surveys were available. We tried several metrics of drift height when establishing our function (peak height, height at a single depth sounder, average height based on two or three sounders). We found that the best regression was for volume vs peak drift height $\left(r^{2}=0.82\right.$ for Barrow; $r^{2}=0.87$ for the combined Franklin Bluffs and Imnavait sites). Unfortunately, the sonic sounders were not always at the correct distance from the fence to capture the peak (which varied from survey to survey), so we used the next best regression $\left(r^{2}=0.77\right)$, which was for drift volume vs average height derived from all three sonic sounders. The vertical wood slat fence at Barrow produced a deep moat at the fence that extended past our $3 \mathrm{~m}$ sounder, so for that fence we used only the 10 and $20 \mathrm{~m}$ sounders to compute the average.

For each of the 36 SDEs (Table 5), we computed the average start and end heights of the drift and the start and end times (accurate to 1 hour) of the events. Using Figure 9, we then computed the start and end drift volume, from which we could then derive the wind-blown deposition flux rate (Table 5). Snow density was assumed to be constant $\left(450 \mathrm{~kg} \mathrm{~m}^{-3}\right)$, a value consistent with our measurements (not shown) and those of Tabler (1980). We also identified the mean and peak wind speed for each SDE, as well as the relative humidity and temperature (Table 5). The resulting flux values are plotted in Figure 10 as a function of wind speed along with data from previous studies.

\section{DISCUSSION}

There have been dozens of experimental studies on the windblown flux of snow. Anyone who has had the misfortune of being caught in a blizzard can appreciate that snow flux measurements are hard to make. Thus, it is not surprising that four major types of methodology have been employed to quantify the flux and nearly as many types of apparatus have been used as studies conducted (i.e. Mellor traps, bag traps, particle counters with and without size identification, acoustical sensors, cameras, snow fences with and without sonic depth sounders). We chose one of the least-used methods because part of our interest is in the study of drift

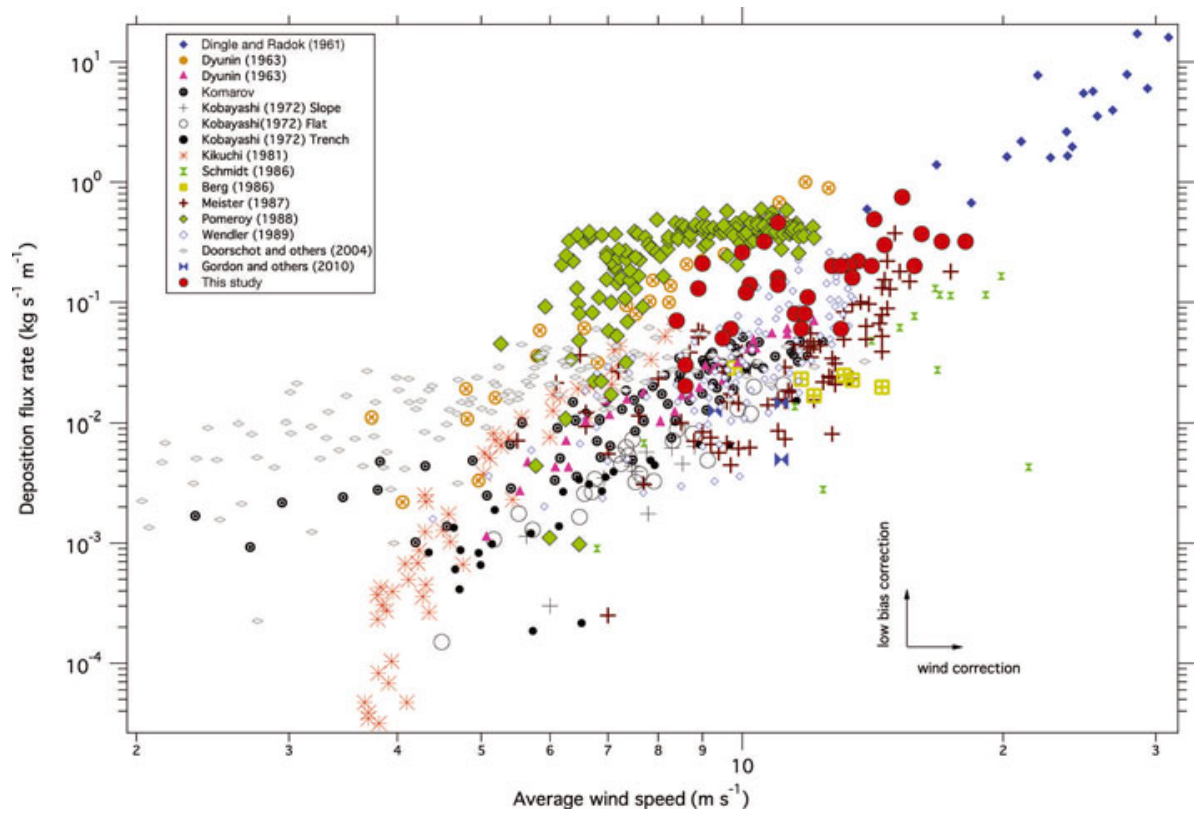

Fig. 10. Wind-blown snow deposition flux rates (solid red circles) from this study plotted as a function of $10 \mathrm{~m}$ wind speed. Data from previous studies (Table 1), digitized from original papers, are also shown. No attempt has been made to correct these older data for wind speed, gauge height or catch efficiency as there is generally not enough information to do so without potentially adding error. The vector schematic inset at the lower right suggests what 'correcting' the data might do: it would shift points up, due to gauge undercatch, and right, due to wind speeds measured at heights $<10 \mathrm{~m}$. The length of the vectors is arbitrary. Data from tundra and polar ice-cap locations (other than this study) are in blue. 
deposits created by the wind-blown flux. We wanted to understand how these deposits might differ across the North Slope of Alaska. To do this, we monitored the flux in three different wind regimes (intermittent moderate southerly flow, steady easterly flow and strong infrequent northeasterly flow). The three sites are all remote, which precluded the use of gauges that require constant human attention. We ruled out using acoustical sensors on the basis of the study by Cierco and others (2007), and optical sensors need continual height adjustment. We also liked the fact that snow fences trap both saltating and suspended snow. Tabler and others (1990) estimate that, until a snow fence is full, it traps 80$90 \%$ of the flux, a respectable amount when compared with apparatus that may have less than half this trapping efficiency (Font and others, 1998). Revision can be verified visually: downwind of an effective snow fence is always a zone where there is virtually no snow on the ground, the result of wind transport out of (but not into) this zone.

In comparing our results with those of previous studies (Fig. 10), we were not surprised that our measurements fall slightly higher than most other data from the polar regions. Rather than taking this to indicate that our values are too high, we take the view that most (if not all) wind-blown flux measurements produce underestimates. Using a snow fence may be one of the more efficient traps, though it is still less than $100 \%$ efficient. Many of the existing measurements (Table 1; Fig. 10) were of saltating snow alone or were made over a limited vertical interval above the snow surface, limiting the amount of suspended snow that contributed to the flux. We are encouraged that (1) the end-of-winter volumes of the drifts we measured are similar to those measured by Tabler and others (1990) for snow fences near Prudhoe Bay, Alaska, and (2) our results align well with the results of Dingle and Radok (1961), who used one of the tallest towers $(4 \mathrm{~m})$ armed with the most (eight) traps and, hence, caught more of the suspended load than most of the other investigations.

There are, of course, uncertainties in our flux values. One need only look at Figure 9 to see that our estimates of volume based on sonic sounder heights potentially could be in error by $\pm 20 \%$. Nevertheless, in addition to being suitable for remote locations, another strength of the snowfence method is that measurement intervals can be long (hours to days), unlike methods employing traps, boxes or trenches that need to be emptied frequently. While those short-period measurements are probably accurate in determining the volume or mass of snow during the measurement interval, they suffer from the fact that we cannot tell whether the interval was truly representative of the flux over a longer period when the wind was varying and the snow conditions were changing. Similarly, continuous measurements using particle counters require assumptions of particle size or mass, which can change rapidly during an SDE as the snow conditions change. For example, the photograph in Figure 11 was taken during a windstorm that was moving large $(6-10 \mathrm{~mm})$ grains exhumed from a depth hoar layer. These grains, which were saltating over the snow surface, were about two orders of magnitude larger than the 'normal' size of wind-blown grains. A number flux alone in this case would not have produced a good estimate of the snow transport. Given these measurement issues, we think snowfence measurements have several advantages - particularly when used with sonic depth sounders - which warrant their greater use in studies of blowing snow.

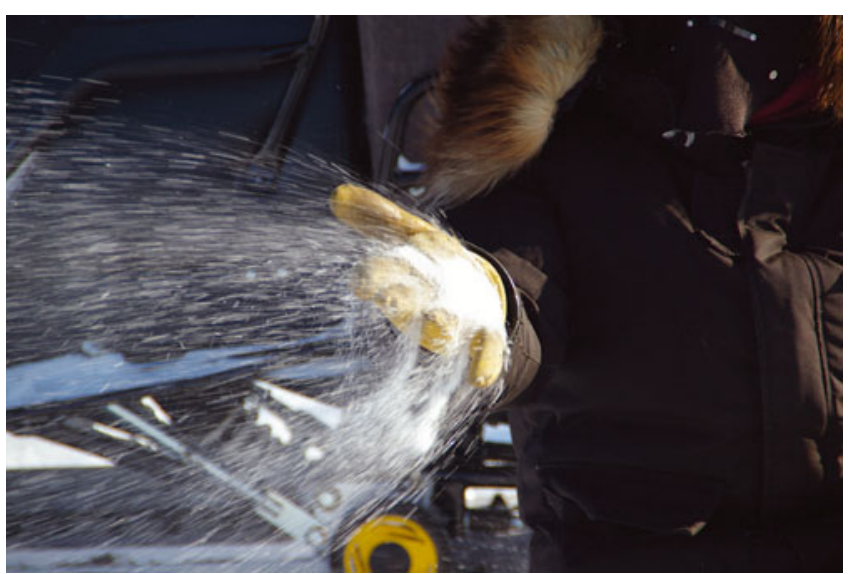

Fig. 11. The snow grains blowing out of the researcher's glove are coarse depth- hoar grains averaging $\sim 6-10 \mathrm{~mm}$ in length. The layers of snow above the depth hoar had eroded away and the wind was now transporting these grains, which were 100 times larger than typical wind-blown grains.

Our purpose here, however, is not to suggest that any particular method is best; it is to suggest that, at this time, the snow research community should turn its attention to a different problem. It is our opinion that, after 50 years of making measurements relating wind-blown snow flux to wind speed (Table 1), the snow research community actually knows this flux quite well (Fig. 10), perhaps as well as it can be known. The large scatter in the data is not a measurement artifact (though some of the scatter can be ascribed to this source), but rather the result of the flux not being a singlevalued function of wind speed. Instead, the flux is a complex interaction of wind speed and character (gusts, lulls, speed, direction; cf. Guyomarc'h and Durand, 2010) and snow surface and subsurface conditions (hardness, grain size, bonding, layering; cf. Schmidt, 1980; Guyomarc'h and Mérindol, 1998; Clifton and others, 2006) which leads to combinations that produce a wide range of fluxes for a given wind speed. Dyunin (1963), Takeuchi (1980), Pomeroy (1988), Tabler and others (1990) and Pomeroy and Gray (1995) all implicitly recognized this point when they produced plots of the published regression equations relating snow flux to wind speed. These researchers used computed regression lines, rather than the actual data, to illustrate the range of results (almost two orders of magnitude at $w=10 \mathrm{~m} \mathrm{~s}^{-1}$ ). Unfortunately, this presentation may have suggested to readers a degree of order not actually found in nature. We suggest that Figure 10, which shows the true scatter in the data, is a good indication of the true nature of wind-blown snow fluxes.

The sensitivity of the flux to factors other than wind speed is manifest in the data groupings visible in Figure 10. Results from individual studies tend to cluster or align parallel to the other data, but at higher or lower values. We speculate that these group separations are the result of differences in the climatological snow and wind conditions at study sites. For example, air temperatures, snow surface grain characteristics and surface features (like sastrugi) are similar on ice caps and on the tundra perennial snow cover (Benson and Sturm, 1993). We have color-coded in blue all the studies in Figure 10 that fall into these two classes. These form a consistent and much tighter linear grouping of the data (all the way from 2 to $30 \mathrm{~m} \mathrm{~s}^{-1}$ wind speed) than the full ensemble, suggesting that within this climatological subset 


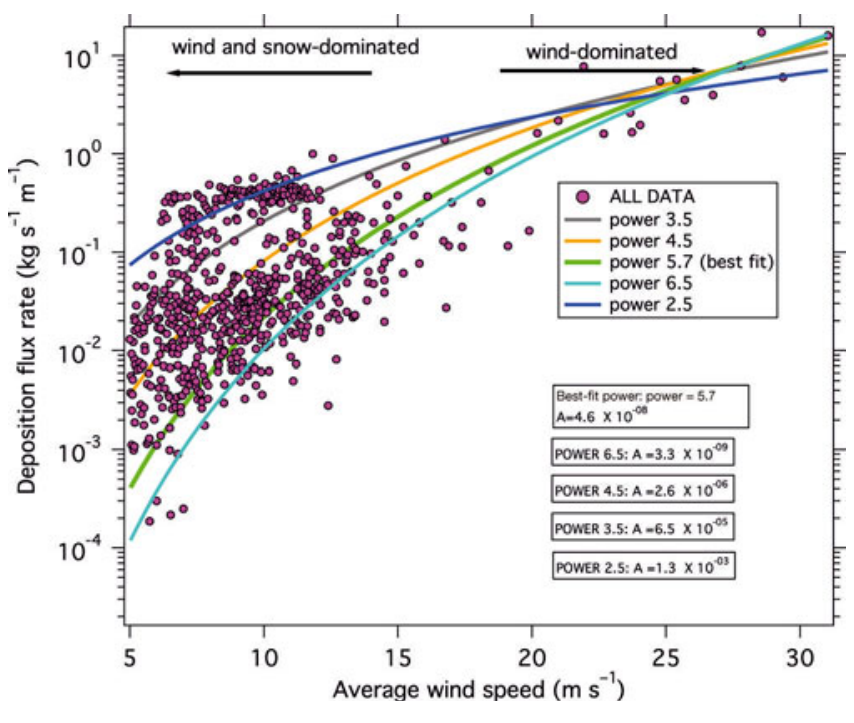

Fig. 12. All blowing-snow flux data from Figure 10, including data from this study, with a series of power curves fit to the data. Upper and lower bounding curves are listed in Eqns (5) and (6) and are suggested as bounding curves for the data.

of all the data, controlling factors other than wind speed are similar. However, a more comprehensive subdividing of the data by snow classes (Sturm and others, 1995) is not possible at this time given the documentation on the published studies in Figure 10. This could prove to be a fruitful avenue of investigation in the future.

What we can do now is to adopt a new 'best practice' for estimating the flux that reflects the reality of existing data. We suggest that it would be as follows: bracket the reliable data with maximum and minimum curves (Fig. 12) and, when faced with estimating the wind-blown flux, use these bracketing curves to estimate a minimum and maximum flux for a given wind speed. Following the lead of many previous snow investigators, we use power functions

$$
\begin{aligned}
& Q_{U}=1.3 \times 10^{-3} w^{2.5} \\
& Q_{\mathrm{L}}=3.3 \times 10^{-9} w^{6.5}
\end{aligned}
$$

where $w$ is the wind speed $\left(\mathrm{m} \mathrm{s}^{-1}\right)$ and $Q$ is the flux $\left(\mathrm{kg} \mathrm{m}^{-1} \mathrm{~s}^{-1}\right)$. In developing these equations, we have excluded all data below $5 \mathrm{~m} \mathrm{~s}^{-1}$ wind speed, which tend to be contradictory (Fig. 10). While the 'best-fit' curve (in a least-squares sense) has a power of 5.7, we do not suggest this curve is any more representative than the other curves for the data. The data and curves in Figure 12 can also be viewed as a comprehensive dataset, representing different climate/snow zones from ice sheet to alpine and arctic environments. The result of this analysis can be developed in such a way that by selecting one or more curves from Figure 12, one can refine computation of the wind-blown flux in a particular snow environment.

Perhaps the most interesting aspect of the family of power curves is their convergence at higher $\left(>15 \mathrm{~m} \mathrm{~s}^{-1}\right)$ wind speeds. While there are only a limited number of data for these higher wind speeds, the flux becomes increasingly single-valued with higher speeds. Conversely, at wind speeds below what is typically thought of as the threshold velocity $\left(\sim 8 \mathrm{~m} \mathrm{~s}^{-1}\right)$, the flux expands almost three orders of magnitude at a given wind speed. We interpret this to indicate that wind dominates snow transport, with snow conditions of decreasing importance, as the wind strengthens. At low wind speeds, the nature of the snow and whether it is snowing while the wind is blowing become increasingly important. For example, only a few types of low-density fluffy snow can be transported at $4-5 \mathrm{~m} \mathrm{~s}^{-1}$ winds. For most types of snow, there will be no transport.

The challenge now is to learn how to identify which end of the functional spectrum (Fig. 12) a particular location, storm, or snow and wind system will be in at a particular time. Until we do this, there will be no quantitative way to narrow down estimates of the flux beyond using the bracketing given in Eqns (5) and (6). A number of investigators have already begun the necessary work. Dyunin (1963), Schmidt (1980), Martinelli and Ozment (1985) and more recently Clifton and others (2006) have investigated the critical shear stress necessary to overcome cohesive forces at the surface of the snow. However, our understanding of how snow and wind interact, how this interaction changes as the snow begins to saltate, and how the snow conditions evolve, remains rudimentary and the models of limited use. Snow layering and quarrying by the wind remain outside our knowledge base. Investigations in these areas, rather than studies of flux as a function of wind speed, are likely to be more useful in the future.

\section{CONCLUSIONS}

Using measurements of changes in drift height at three snow fences in Arctic Alaska, we computed wind-blown snow transport rates. These values ranged from 0.03 to $0.75 \mathrm{~kg} \mathrm{~s}^{-1} \mathrm{~m}^{-1}$ for 36 separate SDEs (snow deposition events) spread over three winters. Average transport rates varied from 0.16 to 0.19 to $0.29 \mathrm{~kg} \mathrm{~s}^{-1} \mathrm{~m}^{-1}$ for our three sites, with the higher values observed in wind regimes where the wind speed was higher but the number of SDEs was lower. Our new values are broadly consistent with published values from 16 other studies. When taken together, these data show a range of more than two orders of magnitude in the flux for a given wind speed, clearly indicating that the wind-blown snow flux is not a single-valued function with respect to wind speed. Other factors (snow conditions, wind direction and character) also affect the flux.

With dozens of studies spanning more than 50 years, we think it unlikely that future studies quantifying wind-blown flux as a function of wind speed are likely to improve much on existing functional equations. We therefore suggest that the existing data are best represented using upper and lower bounding equations $Q_{U}=1.3 \times 10^{-3} w^{2.5}$ and $Q_{\mathrm{L}}=3.3 \times 10^{-9} w^{6.5}$ where $Q$ is the flux $\left(\mathrm{kg} \mathrm{s}^{-1} \mathrm{~m}^{-1}\right)$, $w$ is the wind speed $\left(\mathrm{m} \mathrm{s}^{-1}\right)$ and $U$ and $L$ indicate upper and lower. We think it is time that studies are focused on the remaining essential questions related to blowing snow: How can we best determine the critical value of $u_{*}$, the threshold surface shear stress? How do the snow history and meta-

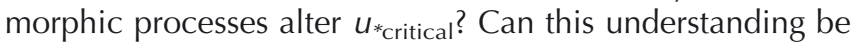
captured in rules or models? Only if we address these questions will we be able to refine our estimates of windblown flux for a particular SDE.

\section{ACKNOWLEDGEMENTS}

Dozens of people helped to collect the data reported here. In particular, we thank Art Gelvin, Chris Hiemstra, Stephanie Saari, Ken Irving, Joel Bailey, Glen Liston, Simon Filhol, Ken 
Tape, Tom Douglas, Andrew Slater and Mark Serreze. Carl Benson was the first to recognize how snow fences could be used to understand blowing-snow fluxes and he retains a keen interest in the subject. Stephen Déry, Ruzica Dadic and an anonymous referee provided valuable comments in review. Logistical support for work in Barrow was provided by the Barrow Arctic Science Consortium and the Ukpeagvik Inupiat Corporation (Umiaq). Logistical support at Imnavait and Franklin Bluffs was provided by Toolik Lake Field Station and $\mathrm{CH}_{2} \mathrm{M}$ HILL Polar Services. The work was supported by a grant from the US National Science Foundation-Office of Polar Programs (SnowNET) and the US Department of Energy, National Energy Technology Laboratory, award No. DE-NT0005684. The paper is dedicated to the memory of Ron Tabler, who did more than anyone else to understand drifting snow and snow fences.

\section{REFERENCES}

Benson CS (1982) Reassessment of winter precipitation on Alaska's Arctic Slope and measurements on the flux of wind blown snow. Geophysical Institute, University of Alaska, Fairbanks, AK (Report UAG-R288)

Benson CS and Sturm M (1993) Structure and wind transport of seasonal snow on the Arctic slope of Alaska. Ann. Glaciol., 18, 261-267

Berg NH (1986) Blowing snow at a Colorado alpine site: measurements and implications. Arct. Alp. Res., 18(2), 147-161

Bintanja R (2001) Snowdrift sublimation in a katabatic wind region of the Antarctic ice sheet. J. Appl. Meteorol., 40(11), 1952-1966 (doi: 10.1175/1520-0450(2001)040<1952:SSIAKW>2.0.CO;2)

Björk RG and Molau U (2007) Ecology of Alpine snowbeds and the impact of global change. Arct. Antarct. Alp. Res., 39(1), 34-43 (doi: 10.1657/1523-0430(2007)39[34:EOASAT]2.0.CO;2)

Black RF (1954) Precipitation at Barrow, Alaska, greater than recorded. Eos, 35(2), 203-206

Box JE and Steffen K (2001) Sublimation on the Greenland ice sheet from automated weather station observations. J. Geophys. Res., 106(D24), 33 965-33 981 (doi: 10.1029/2001JD900219)

Chritin V, Bolognesi R and Gubler H (1999) FlowCapt: a new acoustic sensor to measure snowdrift and wind velocity for avalanche forecasting. Cold Reg. Sci. Technol., 30(1-3), 125-133 (doi: 10.1016/S0165-232X(99)00012-9)

Cierco F-X, Naaim-Bouvet F and Bellot H (2007) Acoustic sensors for snowdrift measurements: how should they be used for research purposes? Cold Reg. Sci. Technol., 49(1), 74-87 (doi: 10.1016/j.coldregions.2007.01.002)

Clifton A, Rüedi JD and Lehning M (2006) Snow saltation threshold measurements in a drifting-snow wind tunnel. J. Glaciol., 52(179), 585-596 (doi: 10.3189/172756506781828430)

Cooley KR, Huber AL, Robertson DC and Zuzel JF (1981) Effects of snowdrift management on rangeland runoff. In Shafer BA ed. Proceedings of the 49th Annual Meeting of the Western Snow Conference, 14-16 April 1981, St George, UT, USA. Colorado State University, Fort Collins, CO, 55-63

Cornish V (1902) On snow-waves and snow-drifts in Canada, with notes on the 'snow-mushrooms' of the Selkirk Mountains. Geogr. J., 20(2), 137-173

Déry SJ and Yau MK (2002) Large-scale mass-balance effects of blowing snow and surface sublimation. J. Geophys. Res., 107(D23), 4679 (doi: 10.1029/2001JD001251)

Dingle WRJ and Radok U (1961) Antarctic snow drift and mass transport. IASH Publ. 55 (General Assembly of Helsinki 1960 Antarctic Glaciology), 77-87

Doorschot JJJ, Lehning M and Vrouwe A (2004) Field measurements of snow-drift threshold and mass fluxes, and related model simulations. Bound.-Layer Meteorol., 113(3), 347-368 (doi: 10.1007/s10546-004-8659-z)
Doumani GA (1967) Surface structures in snow. In Oura H ed. Physics of snow and ice. Institute of Low Temperature Science, Hokkaido University, Sapporo, 1119-1136

Dyunin AK (1963) Solid flux of snow-bearing air flow. NRCC Tech. Translation 1102. National Research Council of Canada, Ottawa

Dyunin AK and Kotlyakov VM (1980) Redistribution of snow in mountains under the effect of heavy snow-storms. Cold Reg. Sci. Technol., 3(4), 287-294 (doi: 10.1016/0165-232X(80)90035X)

Fahnestock MA, Scambos TA, Shuman CA, Arthern RJ, Winebrenner DP and Kwok R (2000) Snow megadune fields on the East Antarctic Plateau: extreme atmosphere-ice interaction. Geophys. Res. Lett., 27(22), 3719-3722 (doi: 10.1029/ 1999GL011248)

Font D, Mases M and Vilaplana JM (1998) Experimental mass-flux measurements: a comparison of different gauges with estimated theoretical data. Ann. Glaciol., 26, 225-230

Gordon M, Biswas S, Taylor PA, Hanesiak J, Albarran-Melzer M and Fargey S (2010) Measurements of drifting and blowing snow at Iqaluit, Nunavut, Canada during the star project. Atmos.Ocean, 48(2), 81-100 (doi: 10.3137/AO1105.2010)

Guyomarc'h G and Durand Y (2010) Key parameters for local drifting snow events. In Proceedings of the International Snow Science Workshop 2010, Squaw Valley, CA. International Snow Science Workshop, 706-711 http://arc.lib.montana.edu/ snow-science/item/470

Guyomarc'h G and Mérindol L (1998) Validation of an application for forecasting blowing snow. Ann. Glaciol., 26, 138-143

Henderson EP (1956) Large nivation hollows near Knob Lake, Quebec. J. Geol., 64(6), 607-616

Hinkel KM and Hurd JKJ (2006) Permafrost destabilization and thermokarst following snow fence installation, Barrow, Alaska, U.S.A. Arct. Antarct. Alp. Res., 38(4), 530-539

Kikuchi T (1981) A wind tunnel study of the aerodynamic roughness associated with drifting snow. Cold Reg. Sci. Technol., 5(2), 107-118 (doi: 10.1016/0165-232X(81)90045-8)

King JC, Anderson PS and Mann GW (2001) The seasonal cycle of sublimation at Halley, Antarctica. J. Glaciol., 47(156), 1-8 (doi: 10.3189/172756501781832548)

Kobayashi S (1972) Studies of snow transport in low-level drifting snow. Contrib. Inst. Low Temp. Sci., Ser. A 24, 1-58 [in Japanese with English summary]

Komarov AA (1963) Some rules on the migration and deposition of snow in western Siberia and their application to control measures. NRCC Tech. Translation 1094. Division of Building Research, National Research Council of Canada, Ottawa

Lewis WV (1939) Snow-patch erosion in Iceland. Geogr. J., 94(2), 153-161

Li S and Sturm M (2002) Patterns of wind-drifted snow on the Alaska arctic slope detected with ERS-1 interferometric SAR. J. Glaciol., 48(163), 495-504 (doi: 10.3189/172756502781831151)

Lied NT (1963) Notes on sastrugi and snow dune observations, A.N.A.R.E. satellite station, Vestfold Hills, 1961. Austral. Meteorol. Mag. 40, 35-46

Liston GE and Sturm M (1998) A snow-transport model for complex terrain. J. Glaciol., 44(148), 498-516

Mahesh A, Eager R, Campbell JR and Spinhirne JD (2003) Observations of blowing snow at the South Pole. J. Geophys. Res., 108(D22), 4707 (doi: 10.1029/2002JD003327)

Martinelli M and Ozment A (1985) Some strength features of natural snow surfaces that affect snow drifting. Cold Reg. Sci. Technol., 11(3), 267-283 (doi: 10.1016/0165-232X(85)90051-5)

Maykut GA and Untersteiner N (1971) Some results from a timedependent thermodynamic model of sea ice. J. Geophys. Res., 76(6), 1550-1575 (doi: 10.1029/JC076i006p01550)

Meister R (1987) Wind systems and snow transport in Alpine topography. IAHS Publ. 162 (Symposium at Davos 1986 Avalanche Formation, Movement and Effects), 265-278

Mellor M and Fellers G (1986) Concentration and flux of windblown snow. CRREL Spec. Rep. 86-11

Moss R (1938) The physics of an ice-cap. Geogr. J., 92(3), 211-231 
Olsson PQ, Hinzman LD, Sturm M, Liston GE and Kane DL (2002) Surface climate and snow-weather relationships of the Kuparuk Basin on Alaska's Arctic Slope. ERDC/CRREL Tech. Rep. TR-02-10)

Pomeroy JW (1988) Wind transport of snow. (PhD thesis, University of Saskatchewan)

Pomeroy JW and Gray DM (1995) Snow accumulation, relocation and management. NHRI Science Report 7. National Hydrology Research Institute, Environment Canada, Saskatoon, Sask.

Schmidt RA (1972) Sublimation of wind-transported snow: a model. USDA Forest Serv. Res. Pap. RM-90

Schmidt RA (1980) Threshold wind-speeds and elastic impact in snow transport. J. Glaciol., 26(94), 453-467

Schmidt RA (1986) Transport rate of drifting snow and the mean wind speed profile. Bound.-Layer Meteorol., 34(3), 213-241

Seligman G (1936) Snow structure and ski fields: being an account of snow and ice forms met with in nature, and a study on avalanches and snowcraft. Macmillan, London

Sturm M and Liston GE (2003) The snow cover on lakes of the Arctic Coastal Plain of Alaska, USA. J. Glaciol., 49(166), 370-380 (doi: 10.3189/172756503781830539)

Sturm M, Holmgren J and Liston GE (1995) A seasonal snow cover classification scheme for local to global applications. J. Climate, 8(5), 1261-1283

Sturm M, Holmgren J and Perovich DK (2002) Winter snow cover on the sea ice of the Arctic Ocean at the Surface Heat Budget of the Arctic Ocean (SHEBA): temporal evolution and spatial variability. J. Geophys. Res., 107(C10), 8047 (doi: 10.1029/ 2000JC000400)

Tabler RD (1975) Predicting profiles of snowdrifts in topographic catchments. In Wastuchek JN ed. Proceedings of the 43rd Annual Western Snow Conference 23-25 April 1975, Coronado, California. Western Snow Conference, Soda Springs, CA, 87-97

Tabler RD (1980) Geometry and density of drifts formed by snow fences. J. Glaciol., 26(94), 405-419

Tabler RD (2003) Controlling blowing and dfifting snow with snow fences and road design. Transportation Research Board of the
National Academies, Washington, DC. (National Cooperative Highway Research Program (NCHRP) Project 20-7(147))

Tabler RD, Benson CS, Santana BW and Ganguly P (1990) Estimating snow transport from wind speed records: estimates versus measurements at Prudhoe Bay, Alaska. In Shafer B, Marron JK and Troendle C eds. Proceedings of the 58th Annual Meeting of the Western Snow Conference, 17-19 April 1990, Sacramento, CA, USA. Colorado State University, Fort Collins, CO, 61-72

Takeuchi M (1980) Vertical profile and horizontal increase of drift snow transport. J. Fac. Sci., Hokkaido Univ., 6(1), 143-156 J. Glaciol., 26(94), 481-492

Thorn CE (1976) Quantitative evaluation of nivation in the Colorado Front Range. Geol. Soc. Am. Bull., 87(8), 1169-1178 (doi: 10.1130/0016-7606(1976)87<1169:QEONIT>2.0.CO;2)

Van den Broeke MR (1997) Spatial and temporal variation of sublimation on Antarctica: results of a high-resolution general circulation model. J. Geophys. Res., 102(D25), 29765-29777 (doi: 10.1029/97JD01862)

Vionnet $\mathrm{V}$ and 7 others (in press) Occurrence of blowing snow events at an alpine site over a 10-year period: observations and modelling. Adv. Water Resour. (doi: 10.1016/j.advwatres. 2012.05.004)

Walker DA, Billings WD and Molenaar JG (2001) Snow-vegetation interactions in tundra environments. In Jones HG, Pomeroy JW, Walker DA and Hoham RW eds. Snow ecology: an interdisciplinary examination of snow-covered ecosystems. Cambridge University Press, Cambridge, 266-324

Wendler G (1989) Measuring blowing snow with a photo-electric particle counter at Pole Station, Antarctica. Polarforschung, 59(1-2), 9-16

Williams LD (1978) Ice-sheet initiation and climatic influences of expanded snow cover in Arctic Canada. Quat. Res., 10(2), 141-149 (doi: 10.1016/0033-5894(78)90097-2)

Zhang Y, Suzuki K, Kadota T and Ohata T (2004) Sublimation from snow surface in southern mountain taiga of eastern Siberia. J. Geophys. Res., 109(D21), D21103 (doi: 10.1029/ 2003JD003779) 